Division of Geological \& Geophysical Surveys

RAW-DATA FILE 2016-10

TRACE-ELEMENT GEOCHEMICAL DATA FROM STREAM SEDIMENTS COLLECTED IN THE TOK RIVER AREA, TANACROSS A-5 AND A-6 QUADRANGLES, ALASKA, IN 2016

\author{
by
}

Travis J. Naibert, Melanie B. Werdon, Lauren L. Lande, and Alicja Wypych

$\$ 2.00$

November 2016

THIS REPORT HAS NOT BEEN REVIEWED FOR TECHNICAL CONTENT OR FOR CONFORMITY

TO THE EDITORIAL STANDARDS OF DGGS

Released by:

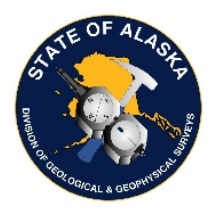

STATE OF ALASKA

DEPARTMENT OF NATURAL RESOURCES

DIVISION OF GEOLOGICAL \& GEOPHYSICAL SURVEYS

3354 College Road | Fairbanks, Alaska 99709-3707

907-451-5010

dggspubs@alaska.gov

dggs.alaska.gov 


\title{
TRACE-ELEMENT GEOCHEMICAL DATA FROM STREAM SEDIMENTS COLLECTED IN THE TOK RIVER AREA, TANACROSS A-5 AND A-6 QUADRANGLES, ALASKA, IN 2016
}

\author{
by \\ Travis J. Naibert ${ }^{1}$, Melanie B. Werdon ${ }^{2}$, Lauren L. Lande ${ }^{1,3}$, and Alicja Wypych ${ }^{1}$
}

\section{INTRODUCTION}

In 2016, geologists from the Alaska Division of Geological \& Geophysical Surveys (DGGS) and University of Alaska Fairbanks carried out a two-part geologic mapping and geochemical sampling project in the Tok River area of the Tanacross A-5 and A-6 quadrangles (June 12-26 and July 8-26). The Tok River area is adjacent to the Delta mineral belt volcanogenic massive-sulfide (VMS) district (Dashevsky and others, 2003), the Peak gold-silvercopper skarn (Illig and Newberry, 2015), and the structurally controlled gold and antimony mineralization in the Stibnite Creek and White Gold areas (U.S. Geological Survey, 2008). The Tok River project area includes the Noah (also called Hona) prospect, an intrusion-related copper prospect (U.S. Geological Survey, 2008). The recently released DGGS Tok airborne magnetic and electromagnetic geophysical survey (Emond and others, 2015) indicates the VMS-prospective stratigraphic horizons described by Dashevsky and others (2003) in the adjacent Delta VMS district may continue into the map area; however, previous reconnaissance mapping (Foster, 1970; Nokleberg and others, 2015) does not provide detail on the stratigraphy and the area's potential mineral prospects. The combination of insufficient detailed geologic mapping, historical and current industry interest in the adjacent mineralized areas, and the recently published geophysical data prompted the DGGS Mineral Resources section to work in this area.

For our Tok River project, DGGS conducted a two-part stream-sediment sampling program to help evaluate the area's mineral-resource potential. An initial suite of sediment samples was collected from streams draining known gold occurrences, including the Stibnite Creek and Noah prospects, and numerous prospects in the White Gold area. These samples were split in half and the two splits were sieved to -200 mesh and -80 mesh, respectively. The splits were then both analyzed to determine which size fraction was best for identifying gold anomalies in this part of the Alaska Range. In most samples, the -200 mesh fraction showed higher gold levels, and hence, all additional samples we collected were analyzed at -200 mesh. In some -80 mesh samples, gold and tungsten appear to show "nugget" effects not seen in the -200 mesh samples. The other trace elements are largely equivalent between the two mesh sizes. The second suite of samples was collected throughout the map area from streams draining color anomalies, from areas where DGGS mapping identified igneous rocks upstream, and from areas with suspected potential for base-metal or gold mineralization. Highlights of the analytical results include two samples draining the Noah prospect with greater than 1 part per million gold.

The analytical data tables associated with this report are available in digital format as comma-separated value (CSV) files. Additional details about the organization of information are noted in the accompanying metadata file. All files can be downloaded from the DGGS website (http://doi.org/10.14509/29688).

Samples collected during this project, as well as laboratory sample rejects and pulps, will be stored at DGGS for the duration of the project and will be available for public viewing upon request. Once the project concludes, the samples and pulps will be stored at the Alaska Geologic Materials Center in Anchorage.

\section{DOCUMENTATION OF METHODS}

\section{SAMPLE COLLECTION}

\footnotetext{
${ }^{1}$ Alaska Division of Geological \& Geophysical Surveys, 3354 College Road, Fairbanks, Alaska 99709-3707

2 Alaska Division of Geological \& Geophysical Surveys, 3354 College Road, Fairbanks, Al;aska 99709-3707; melanie.werdon@alaska.gov

${ }^{3}$ Department of Geology \& Geophysics, University of Alaska Fairbanks, P.O. Box 755780, Fairbanks, Alaska 99775-5780
} 
Stream-sediment sample locations were selected to characterize drainage basins containing igneous intrusions or locations of known or potential mineralization. In the field, sample locations were selected that were upstream of alluvial fans and as close to stream confluences as possible, while also accounting for availability of sample material and proximity to helicopter landing zones. Specific sites at the sample location were selected based on the presence of fine-grained sand and silt, and included eddies or plunge-pools behind boulders or logs, eddies along edges of streams, overbank deposits, and channel bars. Samples were collected with a shovel, screened by hand using a "Garrett's Combination Sifter" with a 0.483-inch square-hole mesh, and then further screened using a 0.0742-inch square-hole mesh (-10 mesh). Undersized material was collected in a 3-gallon plastic bucket and then all materials, fines, and water were poured into polypropylene sample bags (10" x 17") specifically designed to capture fines and allow water drainage. Where possible, the sample bags were filled to capacity to provide enough sample material to split and sieve using both -80 mesh and -200 mesh screens. For the remaining samples, sample bags were filled to approximately 60 percent of capacity. Individual sample weights were measured after drying and are provided in the analytical results.

Location data were collected using Trimble Juno T41/5 WAAS-enabled GPS devices running ArcGIS for Windows Mobile. Data were merged into an ArcGIS geodatabase. WAAS-enabled GPS devices have a reported error of about $1 \mathrm{~m}$. Latitude and longitude are reported in the WGS84 datum.

\section{SAMPLE PREPARATION}

Sediment samples were processed by ALS Minerals using their PREP-41 package. The samples were logged and dried at a maximum temperature of 60 degrees Celsius. An initial batch of 23 samples were each split with a riffle splitter, and sample splits were dry-sieved to <180 microns (-80 mesh) and to <75 microns (-200 mesh), respectively. The remaining 44 samples were dry-sieved to $<75$ microns (-200 mesh).

\section{ANALYTICAL METHODS}

Samples were analyzed for a variety of major and trace elements by ALS Geochemistry using the methods listed below. In addition to ALS Geochemistry's accredited (ISO/IEC 17025-2005) internal quality-control program, DGGS monitored analysis quality with two standard reference materials, a gold standard and a base-metal standard. One of each standard was inserted into each batch of 20 samples submitted to ALS Geochemistry.

a. Trace-element compositions for sediment samples were determined by ALS Geochemistry method ME-MS61: Four-acid digestion followed by inductively coupled plasma-atomic emission spectrometry (ICP-AES) and inductively coupled plasma-mass spectroscopy (ICP-MS).

b. Platinum, palladium, and gold values were analyzed by $30 \mathrm{~g}$ fire assay with ICP-MS finish (ALS Geochemistry method PGM-MS23).

c. Samples that exceeded detection limits for gold were reanalyzed by $30 \mathrm{~g}$ fire assay with atomic absorption (AA) finish (ALS Geochemistry method Au-AA25).

For each sample, data tables contain either assay values or coded-value placeholders (null = not analyzed; $-1=$ the element's assay result is less than the lower detection limit for the method; -2 = the element's assay result is greater than the upper detection limit for the method). Detection limits for each of the reported elemental values obtained by the various methods are documented in the metadata file.

\section{ACKNOWLEDGMENTS}

The DGGS Tok River project is funded through U.S. Geological Survey STATEMAP Award No. G16AC00182; Cooperative Agreement G16AC00167 between the U.S. Geological Survey and the Alaska Department of Natural Resources, Division of Geological \& Geophysical Surveys; and by State of Alaska general funds. 


\section{REFERENCES}

Dashevsky, S.S., Schaefer, C.F., and Hunter, E.N., 2003, Bedrock geologic map of the Delta mineral belt, Tok mining district, Alaska: Alaska Division of Geological \& Geophysical Surveys Professional Report 122, 122 p., 2 sheets, scale 1:63,360. http://doi.org/10.14509/2923

Emond, A.M., CGG, Burns, L.E., Graham, G.R.C., and CGG Land (U.S.) Inc., 2015, Tok electromagnetic and magnetic airborne geophysical survey data compilation: Alaska Division of Geological \& Geophysical Surveys Geophysical Report 2015-2. http://doi.org/10.14509/29347

Foster, H.L., 1970, Reconnaissance geologic map of the Tanacross Quadrangle, Alaska: U.S. Geological Survey Miscellaneous Geologic Investigations Map 593, 1 sheet, scale 1:250,000.

Illig, P., and Newberry, R.J., 2015, Amphibole Au-Cu skarn and massive sulfide replacement at the Peak deposit, Eastern Interior, Alaska, in Proceedings, PACRIM 2015 Congress (Skarn and Replacement Deposits chapter): Melbourne, The Australasian Institute of Mining and Metallurgy, p. 415-422.

Nokleberg, W.J., Aleinikoff, J.N., Bond, G.C., Ferrians, O.J., Jr., Herzon, P.L., Lange, I.M., Miyaoka, R.T., Richter, D.H., Schwab, C.E., Silva, S.R., Smith, T.E., and Zehner, R.E., 2015, Geologic maps of the eastern Alaska Range, Alaska (44 quadrangles, 1:63,360 scale), with descriptions and interpretations of map units: Alaska Division of Geological \& Geophysical Surveys Report of Investigation 2015-6, 64 p., 45 sheets, scale 1:63,360. http://doi.org/10.14509/29444

U.S. Geological Survey, 2008, Alaska Resource Data File (ARDF): U.S. Geological Survey Open-File Report 20081225. 